\title{
Understanding attitude measurement: exploring meaning and use of the PATT short questionnaire
}

\author{
Johan Svenningsson $^{1}$ (D) Magnus Hultén ${ }^{1} \cdot$ Jonas Hallström $^{1}$
}

Accepted: 10 December 2016/Published online: 21 December 2016

(C) The Author(s) 2016. This article is published with open access at Springerlink.com

\begin{abstract}
The pupils' attitudes toward technology survey (PATT) has been used for 30 years and is still used by researchers. Since it was first developed, the validity of the questionnaire constructs has primarily been discussed from a statistical point of view, while few researchers have discussed the type of attitudes and interest that the questionnaire measures. The purpose of this study is to increase the knowledge about student interpretations and the meaning of their answers in the recently developed PATT short questionnaire (PATT-SQ). To research this, a mixed methods approach was used, where the qualitative data from six interviewees (students aged 14) help to explain and interpret the quantitative data from 173 respondents (students aged 12-15). The interviewed students completed a Swedish version of the PATT-SQ 3 weeks prior a semistructured interview. The results from this study imply that the PATT-SQ survey can be used mostly as it is, but this study also shows that there are some categories that require some caution when being analyzed and discussed. For example, the gender category cannot be used as intended since it does not measure what it is supposed to and it might be gender-biased. The interest category can advantageously be reduced to four items to focus on school technology, which will indicate how deep a student's well-developed individual interest is. And the career category seems to only detect students' who urge a career in technology, while the other students lack knowledge about what that career might be and therefore they are not interested in such a career.
\end{abstract}

Keywords Attitudes · Interest · Technology education · PATT

Johan Svenningsson

johan.svenningsson@liu.se

Magnus Hultén

magnus.hulten@liu.se

Jonas Hallström

jonas.hallstrom@liu.se

1 Department of Social and Welfare Studies, Linköping University, 60174 Norrköping, Sweden 


\section{Introduction}

The study of pupils' attitudes toward technology (PATT) has a long history in technology education research. The PATT questionnaire was developed in the 1980s by Raat and de Vries (1986). The researchers intention was to explore students' interest in and attitudes toward technology. In the PATT questionnaire, students' attitudes toward the technological field are surveyed from a range of perspectives, such as their career aspirations in technology, interest in technology and technology education. It was considered interesting to use the data to strengthen the subject's status and to show that technology as a school subject was important for younger children as well. The first results from studies based on the PATT questionnaire showed, for example, that girls found technology less interesting and less important than boys did (Boser et al. 1998). A PATT survey has been conducted once before in Sweden in 1986 and the results were presented in a report in 1991 (Riis and Augustsson 1991).

Research on attitudes toward technology (and attitudes in general) often aims to find student characteristics that can affect a student's attitude, such as gender, socioeconomic background and parents' occupation etc. (Ardies 2015; Davies and Brember 2001; Lindahl 2003). For example, in the analysis of the first PATT study in Sweden, the main focus was on whether students had an abstract or concrete view on technology and what factors affected this. The concrete view is considered to be demonstrated when students see technology mainly as artifacts. The abstract view is when students see technology as a part of something bigger within a context. The biggest effect was dependent on the schools' demographics, for example, students with well-educated parents, who lived in one-family houses, had a more abstract view on technology (Riis and Augustsson 1991). The PATT survey has often been used to point out gender differences in attitudes toward technology (e.g., Bain and Rice 2006; Hendley et al. 1996; Volk and Ming 1999). This is also the case when adding attitudes toward science (and technology), as reported in a systematic review by Potvin and Hasni (2014) where gender differences were the most common theme. Potvin and Hasni also mention a career in science and technology as a commonly researched area.

Since the first PATT studies, the questionnaire has been used on pupils in a range of different countries across Asia, Africa, and new European countries. Even though the first round of PATT studies in the 1980s went through rigorous validation and reliability tests and further development by Bame and Dugger (1989), the past 15 years have resulted in few discussions concerning the survey's validity and reliability beyond controlling the internal reliability and/or confirming unidimensionality by factor analysis (e.g., Ardies et al. 2013). The survey as updated by Ardies et al. resulted in a shortened questionnaire, with fewer items, and this was named the PATT short questionnaire (PATT-SQ). Over the years there have been some discussions concerning the PATT questionnaires, but there is a lack of criticism or discussion about the survey's meaning in recent studies. Examples of problems that have been observed, in a South African study using the PATT questionnaire, are that researchers experienced language difficulties within their context, especially regarding the understanding of the word 'technology' (Van Rensburg et al. 1999). Similar problems may occur in the Swedish language since the word 'technology' (Swedish teknik) can have the same meaning as the word for skill or technique (cf. Mitcham and Schatzberg 2009). In the South African study by Van Rensburg et al. (1999) the gender items were also pointed out as problematic since they were non-neutrally expressed. Furthermore, several studies have found that students tended to use the middle option on the Likert scale items 
in the PATT questionnaire, especially girls (Burns 1992; de Klerk Wolters 1989; Rennie 1988). This would affect mean scores and is explained through the fact that girls tend to look at a statement in a more complex way, and more often choose the middle option when statements have to do with something that they have not yet thought about (Rennie 1988).

\section{Swedish context}

Technology as a school subject has been mandatory in compulsory school (school year 1-9) in Sweden since 1982 (Hallström et al. 2014). The national curriculum has been changed and revised several times since then. The last major revision was made in 2011 (The Swedish National Agency for Education 2011), where the following aim can be read in the technology syllabus:

Teaching should help students to develop their interest in technology and their ability

to deal with technical challenges in a conscious and innovative way.

(The Swedish National Agency for Education 2011, p. 254)

This aim, to develop interest in the school subject of technology, is not unique to technology; actually developing interest is an aim of all compulsory school subjects except for the social science subjects (The Swedish National Agency for Education 2011). There is an extensive use of this attitude construct in the Swedish curricula and the word 'interest' is referred to more than 50 times.

Since the implementation of the 2011 national curriculum, there has been one quality audit of the technology subject performed by the Swedish school inspectorate. The attitudes of Swedish students were surveyed and the results showed that interest, enjoyment and the perceived importance of technology decreased throughout school years five to nine (ages 11-15), among girls an even larger decrease than with boys (Skolinspektionen 2014). That interest decrease with age in these age groups has also been shown in a Belgian longitudinal study (Ardies et al. 2014). Due to the strong emphasis on interest (and attitudes) in Swedish school curricula, more understanding of what the PATT survey can tell us about students' attitudes is needed. To be able to use data in research there is a need to understand the different survey categories and how students interpret the survey. This will allow us to understand what might affect their attitudes and in turn how technology education may be improved in relation to aims related to attitudes.

\section{Purpose of the study}

The purpose of this study is to increase the knowledge about student interpretations and the meaning of their answers in the recently developed PATT short questionnaire (PATT-SQ). Thereby, a better understanding of results from studies using the PATT-SQ (by Ardies et al. 2013) can be gained, so that such studies can better inform us about student attitudes and in turn better inform how technology education may be improved in relation to aims related to attitudes. Taking previous research into consideration, the focus of the study will be on gender problems as discussed by Burns (1992), de Klerk Wolters (1989), Rennie (1988) and the non-neutral expressed statements by Van Rensburg et al. (1999) as well as the possible misinterpretation of the term 'technology' (cf. Mitcham and Schatzberg 2009). The fact that gender and career aspirations are two of the most researched areas (see Potvin and Hasni 2014) makes it relevant to focus on these themes. The interest construct will also be analyzed, since it can be seen as both a field by itself and a construct within attitudes. The research questions for this study are; How can student interpretations and the meaning 
of their answers in the PATT-SQ questionnaire be understood? What can the result tell us about students' career aspirations, interest and gender issues in technology?

\section{Theoretical background}

\section{Attitudes}

Both attitudes and interest can be seen as motivational variables (Krapp and Prenzel 2011) and interest can be seen as a construct within a person's attitude (de Klerk Wolters 1989). Attitudes can be seen through three components; affective, behavioral and cognitive (Breckler 1984; Fishbein and Ajzen 1975). Attitudes toward a topic (like technology) are based on a person's beliefs about that topic and those beliefs have an influence on the behavior (Fishbein and Ajzen 1975). A person's beliefs, can, on the other hand, be weakened or strengthened and even replaced, which can lead to a change in attitude. In some cases, attitudes toward technology positively correlate with students' knowledge (Garmire and Pearson 2006), meaning that a clearer concept of technology among pupils, would also improve positive attitudes toward technology (Rohaan et al. 2010).

The early versions of the PATT questionnaire (e.g., Bame and Dugger 1989) include two main parts. One part where the cognitive component is surveyed by 31 statements. And one part, the PATT survey's main part, including 58 statements (same as the part that was shortened and named PATT-SQ) that is suitable for assessing a students' affective component (Ankiewicz et al. 2001; Van Rensburg et al. 1999). This means that the student's emotional engagement in technology and technology education is surveyed. The PATT questionnaire also includes an essay type question about technology and one part surveying student characteristics (Bame and Dugger 1989).

\section{Interest}

Interest is one category within the PATT questionnaire that is surveyed, but what kind of interest does the survey measure? A person's knowledge can at any time become an object of interest (Krapp 2002). It can be stated that an interest has to be toward something, for example, technology education (Krapp and Prenzel 2011) and it can be seen as a motivational factor for becoming engaged with the subject (Hidi and Renninger 2006; Krapp 2002). Interest can be divided into Situational Interest and Individual Interest. Situational interest can take place in a specific situation that will trigger an interest, while individual interest is based on the person's own underlying beliefs (Hidi and Renninger 2006). On a more general level, some studies have found that interest in a subject can correlate positively with knowledge in that subject, especially in higher grades (Krapp 1999).

Hidi and Renninger (2006) identify four phases of interest that can be used to reach a higher state of interest among students in school. The first phase is triggering situational interest followed by maintaining that interest in the second phase. The next phase is to develop an individual interest which mostly is self-generated, but can be assisted by tasks that will lead to an increased understanding of the specific subject. The fourth phase is a well-developed individual interest, characterized by positive feelings about the subject and an urge to become more deeply engaged in the specific object of interest.

The PATT-SQ surveys' statements regarding interest focus on the will to gain more knowledge, especially through school technology. A high mean score on the interest scale should, therefore, indicate a well-developed individual interest, as presented by Hidi and Renninger (2006). 


\section{Method}

In order to gather more knowledge about what the PATT questionnaire can tell us about what affects pupils' attitudes toward the technology subject and technology in general, a mixed methods approach was used with a modified PATT-SQ questionnaire and interviews with pupils that had taken the questionnaire. With this Sequential exploratory design, the qualitative data will help to explain and interpret the quantitative data; the students' survey score (Robson 2011).

\section{Quantitative data collection}

To measure students' interest in and attitudes toward technology, PATT-SQ was used (see Ardies et al. 2013). The survey consists of 24 items which the student responds to on a 5 -point Likert scale. The respondent chooses how well he or she agrees with a statement. To analyze the data the items are grouped into several constructs/categories (Lovelace and Brickman 2013). The used PATT-SQ survey (Ardies et al. 2013) consists of six different categories which are presented below with an item example:

1 Career-Respondents' career aspirations in technology

Example item: "I would like a career in technology later on"

2 Gender-Gender patterns in technology

Example item: "Boys are able to do practical things better than girls"

3 Consequences-Consequences and importance of technology

Example item: "Everyone needs technology"

4 Interest-Interest in technology and technology education

Example item: "There should be more education about technology"

5 Difficulties-Perceived difficulty in the technology subject

Example item: "To study technology you have to be talented"

6 Boredom-Perceived boredom with technology

Example item: "I do not understand why anyone would want a job in technology"

To control the categories internal reliability, Cronbach's alpha $(\alpha)$ was measured for each category (Lovelace and Brickman 2013). The aim is an $\alpha$-value $>0.70$ as recommended by Lovelace and Brickman (2013). In this specific study, the interest category was reduced, from six to four statements, to enhance focus on interest in school technology and not technology in general. This is because an interest in something can be followed by an engagement in the same (Hidi and Renninger 2006; Krapp 2002): in this case an engagement in the school subject of technology. All six statements were surveyed, but the four statements regarding school technology can be analyzed separately.

The gender items were elaborated into three different survey versions, to test potential problems related to the items. The first survey version included the original three statements "Boys are able to do practical things better than girls (referred to as Gender M)" (Ardies et al. 2013; Bame and Dugger 1989). The second survey version included the same three statements, but boys was changed to girls "Girls are able to... (referred to as Gender F)", The third survey version included both types of statements "boys are able to... and girls are able to... (referred to as Gender $\mathrm{F}+\mathrm{M}$ )". This made it possible to study the impact of the non-neutral statements problematized by Van Rensburg et al. (1999). The first (53) respondents were given the survey versions containing either the Gender $\mathrm{M}$ or 
Gender F statements randomly, and the later ones (120) were given the third survey version with both types of statements.

In total, four schools were visited to gather data for the study. The schools were selected based on a convenience sample with the intention to get a result from different school types. The sample includes one suburban school, one small town school and two private schools (one urban and one countryside suburban) from different areas and different profiles. In a first round, students in school years 6-8 (aged 12-14) completed the survey, in total 141 students. The survey was distributed in person via one of the researchers, in this way the researcher could easily respond to students' potential questions regarding the survey. To broaden the results, an additional distribution was made, including two more classes in one of the schools (32 students in school years 8-9, aged 14-15), they completed the survey online.

\section{Qualitative data collection}

The qualitative data were collected by conducting semi-structured interviews, with the survey as the basis for the questions, to let the respondents speak more freely about the different topics (e.g., the Likert scale, Career, Interest, and Gender). The intention was to extract more information from the respondents than the survey does (Robson 2011). By the sequential exploratory design, the interviews could enable understanding and interpreting, of how the respondent:

- Survey scores match the answers given in an interview situation.

- Chose a specific number on the 5-point Likert scale.

- Interpreted the different items.

- Interpreted the word 'technology' in the survey.

The interviewees (six 14-year-olds, three boys, and three girls) were chosen by their teacher with the instructions to choose a variety of students that she experienced had differences in knowledge and interest level in the technology subject. The six interviewed students represent a quarter of their class in school year 8. Since knowledge affects attitudes (Rohaan et al. 2010) an aim of the purposive sample was to get a variety of attitudes (reaching from positive to negative) within the studied survey categories (Career, Interest, and Gender). To prevent bias, these students' level of knowledge and interest was unknown to the researchers. They completed the PATT-SQ survey 3 weeks prior to the interview and their survey results were not included in the quantitative sample. Since all six students belonged to the same school class and had the same technology teacher; the natural variety between schools could be excluded. Therefore, all interviewees had participated in the same technology education class, conducted by the one teacher. They had all participated in technology lessons at age 13, but not during their current semester. The interviews lasted for approximately $15 \mathrm{~min}$. The interviews were audio-recorded and transcribed. Student answers were labeled according to the PATT-SQ survey categories (e.g., Career, Interest, Gender) in the qualitative data analysis software program MAXQDA. This was done to detect underlying thoughts about career, interest and gender issues, where questions had not been specifically directed toward these topics.

\section{Compliance with ethical standards}

The ethical research principles for research in the humanities and social sciences put forward by the Swedish Research Council regarding "information, consent, and 
confidentiality, and stipulating how research data may be used" was used (Petersson et al. 2006, p. 83). All participating students were informed about the study, its use and their right to choose to participate or not. All respondents participated anonymously and completed the whole survey. All interviewees agreed to participate in the interview and their legal guardians approved their participation.

\section{Results}

The total number of respondents to the survey was 173 (89 girls, 81 boys, 3 N/A). Four of the respondents failed to fill in the paper survey correctly and thus their responses were discarded. In total, there were 169 countable respondents. In addition to this, there were six student interviewees. The results from the qualitative sample can, in a strict sense, only be seen as representative of the six interviewed students, but we argue that the number of students is enough to detect possible problems of interpreting the survey. This since the aim of the qualitative sample collection was to get a variation in attitudes among the interviewees. This variation was clear in both the Career and Interest category (presented in Tables 3,7). The Gender category was not suitable for mean calculations and therefore variation in mean scores cannot be met (presented in Table 4). The survey and interview results are presented below. The results are presented from how the Likert scale is interpreted, the complete PATT-SQ survey and presentations of the results where the interview and the questionnaire were analyzed jointly in relation to the different categories. The interview questions asked directly toward the topic (e.g., the career category) are presented in the result section for each of the topics.

Researcher's questions, when present, are highlighted by; $\mathbf{R}$

The interviewees' responses are only presented by their sex and not by name or numbers since we find no reason to compare the individuals' other category answers.

\section{Likert interpretations}

Regarding the problem that girls tend to use the middle option more frequently than boys as revealed in several studies (e.g., Burns 1992; de Klerk Wolters 1989; Rennie 1988) a goal was to understand how the Swedish students in this study interpreted the middle option. To be able to compare the results from Rennie (1988), results in Table 1 are presented in the same way as in that study.

The results presented in Table 1 imply that there might be some differences between the sexes, but very small differences if compared to the studies presented by Rennie (1988, p. 402)

Table 1 Gender difference in choice of the middle option for the 27 items in PATT-SQ Sweden

\begin{tabular}{lllll}
\hline & $\begin{array}{l}\text { Girls more use of } \\
\text { middle option }\end{array}$ & $\begin{array}{l}\text { Difference less } \\
\text { than 5\% }\end{array}$ & $\begin{array}{l}\text { Boys more use of } \\
\text { middle option }\end{array}$ & $\begin{array}{l}\text { Total number of } \\
\text { items }\end{array}$ \\
\hline $\begin{array}{l}\text { Number of } \\
\text { items }\end{array}$ & 9 & 13 & 5 & 27 \\
\hline
\end{tabular}


All of the six interviewed students agreed quite well on how they filled out the survey and chose the options on the Likert scale. The students were asked when to choose the middle option on the Likert scale.

It's when you don't know if you agree or disagree.

They are like, I'm not certain, you might think both sides and don't know what to choose.

That you're not sure.

That you're not sure if you agree or not.

Their interpretations of the Likert scale were similar and they used the middle option when they did not know if they agreed or disagreed.

Some of the items in the survey were negative statements, which the respondents seemed to understand and chose the Likert option they intended. However, one of the interviewed students misinterpreted one of the negative statements and checked that he was not interested in technology even though he had a strong interest.

Well, then I believe I must have misread it, I am interested.

\section{The survey}

Cronbach's $\alpha$ was used to measure the internal reliability within the six different categories. Each category had to have an $\alpha>.70$ (Lovelace and Brickman 2013). The Cronbach's $\alpha$-value is presented with the mean values of each of the categories in Table 2 . The different items in each category correlated well with one another except within the Boredom category. With that exception, the results of Cronbach's $\alpha$ showed that the translation and adaption for a Swedish context were reliable. $T$ tests were performed in the areas of focus for this study (Career, Gender, and Interest) and are presented in Table 2. They show that there was mostly a moderate effect $[.01=$ small, $.06=$ moderate, $.14=$ large effect (Cohen 1988)], in the attitudes, depending on the respondent's gender. An exception was the Gender category, which changed from a small effect to a large effect, depending on how the statements were presented.

\section{Career}

This category is supposed to tell us if the respondent is, or is not interested in pursuing a technological career. The Cronbach's $\alpha$ value of the career category is acceptable at .91 and therefore reliable. Questions asked to the interviewees were; if they would like a career in technology and what that career might be and their answers are presented in Table 3.

The performed interviews showed that very few of these students seemed to have an idea of what a technological job might be or at least find it difficult to describe. The highmean interviewees $(>4.00)$ in this study all referred to a technological career as an engineer and/or architect. While the low-mean students $(<3.00)$ used the word 'technician' for technology-related work, and in the interviews, these students were urged to explain what they meant in detail. The high-mean students, on the other hand, seemed to be satisfied with just the words 'engineer' or 'architect'. The interviews showed that independently of whether you understand what a job in technology is or is not, a high mean describes an urge to pursue such a career. The low-mean students were not willing to totally cut off that future path, mostly because they were uncertain of what it means. The high-mean students did not give a clearer view of what this career might be. 
Table 2 Cronbach's $\alpha$, means, and independent-samples $t$ test (career, gender, and interest)

\begin{tabular}{|c|c|c|c|c|c|c|c|c|}
\hline Category & $\begin{array}{l}\mathrm{N} \\
\text { items }\end{array}$ & $\begin{array}{l}\mathrm{N} \text { valid } \\
\text { respondents }\end{array}$ & $\alpha$ & $\begin{array}{l}\text { Boys }=79 \\
\text { Girls }=87\end{array}$ & Mean & Std. & $t$ & $\eta^{2}$ \\
\hline \multirow[t]{3}{*}{1 Career } & \multirow[t]{3}{*}{4} & \multirow[t]{3}{*}{169} & \multirow[t]{3}{*}{.91} & Total & 2.87 & 1.07 & \multirow[t]{3}{*}{-4.42} & \multirow[t]{3}{*}{$0.106 * *$} \\
\hline & & & & Boy & 3.25 & 1.08 & & \\
\hline & & & & Girl & 2.55 & .95 & & \\
\hline \multirow[t]{3}{*}{ 2a Gender M } & \multirow[t]{3}{*}{3} & \multirow[t]{3}{*}{156} & \multirow[t]{3}{*}{.90} & Total & 2.57 & 1.19 & \multirow[t]{3}{*}{-5.83} & \multirow[t]{3}{*}{$0.183 * *$} \\
\hline & & & & Boy & 3.11 & 1.15 & & \\
\hline & & & & Girl & 2.1 & 1.01 & & \\
\hline \multirow[t]{3}{*}{ 2b Gender F } & \multirow[t]{3}{*}{3} & \multirow[t]{3}{*}{130} & \multirow[t]{3}{*}{.87} & Total & 2.25 & 0.99 & \multirow[t]{3}{*}{2.70} & \multirow[t]{3}{*}{$0.054 *$} \\
\hline & & & & Boy & 1.99 & 0.82 & & \\
\hline & & & & Girl & 2.45 & 1.06 & & \\
\hline 2c Gender $\mathrm{F}+\mathrm{M}$ & 6 & 115 & .86 & & - & - & & \\
\hline \multirow[t]{3}{*}{3 Consequences } & \multirow[t]{3}{*}{4} & \multirow[t]{3}{*}{162} & \multirow[t]{3}{*}{.72} & Total & 3.98 & 0.75 & & \\
\hline & & & & Boy & 4.11 & 0.66 & & \\
\hline & & & & Girl & 3.9 & 0.78 & & \\
\hline 4a Interest & 6 & 166 & .76 & Total & 3.09 & 0.88 & & \\
\hline \multirow{3}{*}{$\begin{array}{l}\text { 4b Interest (school } \\
\text { technology) }\end{array}$} & \multirow[t]{3}{*}{4} & \multirow[t]{3}{*}{166} & \multirow[t]{3}{*}{.79} & Total & 3.16 & 1 & \multirow[t]{9}{*}{-4.12} & \multirow[t]{9}{*}{$0.095^{* *}$} \\
\hline & & & & Boy & 3.5 & 0.94 & & \\
\hline & & & & Girl & 2.89 & 0.95 & & \\
\hline \multirow[t]{3}{*}{5 Difficulties } & \multirow[t]{3}{*}{4} & \multirow[t]{3}{*}{168} & \multirow[t]{3}{*}{.74} & Total & 2.68 & 0.86 & & \\
\hline & & & & Boy & 2.96 & 0.80 & & \\
\hline & & & & Girl & 2.45 & 0.84 & & \\
\hline \multirow[t]{3}{*}{6 Boredom } & 4 & 168 & .63 & Total & 2.46 & 0.88 & & \\
\hline & & & & Boy & 2.27 & 0.81 & & \\
\hline & & & & Girl & 2.60 & 0.69 & & \\
\hline
\end{tabular}

$* p<.05$ (2-tailed)

$* * p<.001$ (2-tailed)

\section{Gender}

The Gender category is supposed to tell us if the respondent experiences technology as an activity for both boys and girls. The Cronbach's $\alpha$ value is acceptable, at .90 for gender M and .87 (see Table 2) for gender F thus the Gender category is reliable either way it is presented. However, the category shows that there are some differences in the answers, depending on how the item is presented. Both boys and girls tended to agree more when the statement started with their own sex, for example, boys agreed more when the statements were phrased as Boys are more capable... (see means of category $2 \mathrm{a}$ and $2 \mathrm{~b}$ in Table 2). Adding the fact that the Cronbach's $\alpha$ value is .86 (see Table 2) when the Gender $\mathrm{M}$ and Gender F statements are presented as opposites, shows that there are some issues that might make this category unreliable. The questions asked during the interviews were how the respondents perceived the statements regarding gender and how they would explain their thoughts about those statements (Table 4).

The interviews showed that the mean score does not reflect the students' thoughts on technology as an activity for both boys and girls, therefore the mean score is unreliable. 
Table 3 Student responses in interview regarding technological careers, sorted by career mean

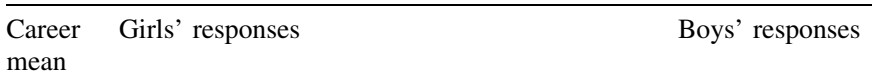

$2.00 \quad$ I'm pretty confident that I won't be working with that [technology], I'm not really sure that I know what a technician might do [...] When I think of a technician, I think of someone sitting in front of a computer and that might be why I don't want to work in it. You might work in a factory perhaps, that produces something. I really don't know much about this. Maybe that's why I'm not that interested

2.50 I haven't got a clue [what a technological profession might be], but maybe if you want to be like a carpenter, you need to be like handy...If you want things to function together, like screws and nuts...but like a plumber, since they kind of need to understand what is wrong and make it work again

R: Would you like a job as a plumber?

Not a plumber specifically, but if I don't like technology, then maybe I shouldn't work with it, then I might begin to like technology first

R: So if you like technology that might be a career path?

Yes, because then you kind of like tinkering with and repairing stuff

Maybe a technician.[is a technological profession]

R: What do they do then?

They connect wires and stuff, maybe?

Maybe an architect, or engineer, or like when you draw different stuff so you can push computers to their limit [...] Those jobs seem fun, I want to work with that in the future[...]Most jobs have something to do with technology[...]like if you are an electrician you need a good technique [Swedish teknik] when connecting wires to an alarm as well as a carpenter does

Well, I believe that I would enjoy being an engineer and come up with ideas for different inventions, because I like being creative in that way[...]I'm kind of knowledgeable in technology and stuff, so I think I have a good chance working in it, I think that I would enjoy that 
Table 3 continued

Career Girls' responses $\quad$ Boys' responses

mean

4.75 [A technological career is] engineer, or like an architect or something

R: Why would you want to work with technology?

Because it pays good money (laughter). No, maybe because I find it interesting and stuff. My dad is an engineer so I have seen what he does

Table 4 Student responses in interview regarding technology and gender, sorted by gender mean

\begin{tabular}{|c|c|c|}
\hline Gender mean & Girls' responses & Boys' responses \\
\hline $\begin{array}{l}\mathrm{F} \text { mean } 1.00 \\
\mathrm{M} \text { mean } 1.00\end{array}$ & $\begin{array}{l}\text { Boys and girls are kind of the same; they } \\
\text { have equal knowledge about } \\
\text { technology. It is not like one knows } \\
\text { more about technology. Well I know } \\
\text { that some people believe that boys are } \\
\text { better at stuff, but I don't think so, I } \\
\text { can't understand why they think that }\end{array}$ & \\
\hline $\begin{array}{l}\text { F mean } 1.00 \\
M \text { mean } 1.00\end{array}$ & $\begin{array}{l}\text { Like in technology class, it depends on } \\
\text { how much you have learned }\end{array}$ & \\
\hline $\begin{array}{l}\mathrm{F} \text { mean } 1.00 \\
\mathrm{M} \text { mean } 1.00\end{array}$ & & $\begin{array}{l}\text { I believe it varies from person to person, } \\
\text { a girl might be better than, or a woman } \\
\text { might be better at a job than a man. It } \\
\text { kind of varies, it depends on the person }\end{array}$ \\
\hline $\begin{array}{l}\text { F mean } 2.67 \\
\text { M mean } 3.33\end{array}$ & & $\begin{array}{l}\text { I didn't know it was between these two. I } \\
\text { would have hoped that it could be } \\
\text { something in between. But I was } \\
\text { thinking like this: from my } \\
\text { perspective, girls haven't been exactly } \\
\text { as good as boys, that I know of. But } \\
\text { overall, some might be, and many } \\
\text { [girls] could know more }\end{array}$ \\
\hline $\begin{array}{l}\text { F mean } 2.33 \\
M \text { mean } 3.67\end{array}$ & & $\begin{array}{l}\text { I think that boys might be more inventive } \\
\text { in technology, but there are girls who } \\
\text { are inventive as well. Boys might be } \\
\text { more interested in technology and } \\
\text { chemistry and stuff }\end{array}$ \\
\hline $\begin{array}{l}\text { F mean } 3.00 \\
M \text { mean } 4.00\end{array}$ & $\begin{array}{l}\text { I believe the reason that boys are more } \\
\text { commonly found in technological jobs } \\
\text { I think is because they have a greater } \\
\text { interest than girls. I really think that is } \\
\text { the only reason, because I think girls } \\
\text { could perform just as well if they were } \\
\text { more engaged }\end{array}$ & \\
\hline
\end{tabular}

This since some interviewees said that they either used the middle Likert option or the disagree option within this category consistently, which made the mean values unreliable. The interviewees' answers are supported when calculating the difference in scores 
Table 5 Gender difference: frequency table when subtracting gender $\mathrm{F}$ mean from gender $\mathrm{M}$ mean

\begin{tabular}{lrcc}
\hline Difference & Frequency & $\begin{array}{l}\text { Valid } \\
\text { percent }\end{array}$ & $\begin{array}{l}\text { Cumulative } \\
\text { percent }\end{array}$ \\
\hline-3.33 & 1 & 0.9 & 0.9 \\
-3.00 & 3 & 2.6 & 3.5 \\
-2.00 & 1 & 0.9 & 4.3 \\
-1.67 & 1 & 0.9 & 5.2 \\
-1.33 & 2 & 1.8 & 7.0 \\
-1.00 & 3 & 2.7 & 9.6 \\
-0.67 & 6 & 5.2 & 14.8 \\
-0.33 & 8 & 7.0 & 21.7 \\
0.00 & 48 & 41.7 & 63.5 \\
0.33 & 11 & 9.6 & 73.0 \\
0.67 & 10 & 8.6 & 81.7 \\
1.00 & 6 & 5.2 & 87.0 \\
1.33 & 4 & 3.5 & 90.4 \\
2.00 & 2 & 1.7 & 92.2 \\
2.33 & 5 & 4.3 & 96.5 \\
2.67 & 2 & 1.7 & 98.3 \\
3.33 & 1 & 0.9 & 99.1 \\
3.67 & 15 & 0.9 & 100.0 \\
Total & 100.0 & \\
\hline & & & \\
\hline
\end{tabular}

Table 6 Gender difference: descriptive statistics when subtracting gender $\mathrm{F}$ mean from gender $\mathrm{M}$ mean

\begin{tabular}{lllllll}
\hline & N & Minimum & Maximum & Mean & SD & Median \\
\hline Gender difference & 115 & -3.33 & 3.67 & .19 & 1.12 & 0.00 \\
Valid N (listwise) & 115 & & & & & \\
\hline
\end{tabular}

subtracting the means of Gender $F$ from the means of Gender $M$ (Table 5). That result reveals that $41.7 \%$ of the respondents chose the same option for every statement (all six statements), even the opposite ones. If the "gender difference" is calculated, the mean difference between Gender $\mathrm{M}$ and Gender F statements is 0.19 , which implies that there is a little more agreement on the statement boys are more capable..., see Tables 5 and 6 .

All interviewees expressed that differences between boys and girls had to do with individuals, rather than sex. The interviewees explained their own results as they chose the disagree option or not sure option consistently. However, some of the interviewed students indicated that there might be differences, but mostly connected this to either more males being active in a technological career or that males, in general, have a greater interest and therefore performing better in technology. 
Table 7 Student responses in interview regarding interest in technology, sorted by interest mean

\begin{tabular}{lll}
\hline $\begin{array}{l}\text { Interest } \\
\text { mean }\end{array}$ & Girls' responses & Boys' responses
\end{tabular}

2.67 It is one of the more enjoyable school subjects [technology] because you get to work with your hands....after history, English, arts and French

R: Where does the interest in a school subject come from?

It has to do with what you as an individual like doing, if you like it you become more interested... and more engaged with the subject... sometimes influenced by friends, but not for me, and sometimes by teachers who make it fun

2.83 I think technology is interesting but I don't find it enjoyable, it doesn't really cohere, I know [...] I believe that smartphones and stuff, that is technology, and I find that interesting... I kind of use my smartphone every day, then I learn, but if I don't understand, it wouldn't be as fun

I don't know where the interest comes from, I have kind of always been interested in technology and of course there is $\mathrm{L}^{* * * *}$, she is a good teacher[...]I think it has to do with when you're good at something it becomes more fun

I think it's fun [technology], it's kind of practical stuff and that is always fun[...]Well it's like when we are talking in class and listen to the teacher talking about interesting things and stuff that I didn't know before...I enjoy other subjects as well, but don't find them as interesting...my interest comes from the school teaching

Well I have always been interested in computer technology and football where I use a lot of technique [Swedish teknik]

My interest comes from playing a lot of video games as a kid... and using computers, wanting to know how to make and editing movies and stuff... I used to watch videos on YouTube to learn[...]I live outside of the town center and didn't have a lot to do and was always interested in how stuff functions[...]My friend's dad works with computers and he has taught me a lot. It has always been fun working with computers and stuff

\section{Consequences}

The consequence category carried the highest mean value of all the categories. Students believed that technology is important to us. The Cronbach's $\alpha$ value was acceptable .72 and 
reliable (see Table 2). The interviewed students said that technology "obviously" was important since they used it every day.

\section{Interest}

The Cronbach's $\alpha$ value was acceptable at .76 for the Interest category and slightly higher when only including the items concerning interest in technology education (.79 in Table 2). This category was, therefore, reliable. In Table 7 the interviewees' responses to questions about interest in general, their interest in technology and where that interest/ noninterest might come from are presented.

The interviewees commonly referred to interest by saying a subject was interesting since they found enjoyment within that subject. Only one of the interviewed students noted a difference between those. Interviewees with both high and low interest said that an interest makes you willing to learn more, or the other way around, knowledge is followed by an interest. The interviews revealed that the interest level in the survey matched what was said in the interview quite well, despite their interpretation of interest as enjoyment. On the other hand, there is only one statement in the interest category that actually contains the word interest. The students' descriptions of interest are similar to what would be considered a well-developed individual interest (Hidi and Renninger 2006).

\section{Difficulties}

The difficulties category shows how the respondents perceived difficulties in technology and that you need specialist competence to study to become, for example, an engineer. The Cronbach's $\alpha$ value was acceptable .74 (Table 2), and therefore reliable as a category. The interviews confirmed that this category was interpreted as intended.

\section{Boredom}

At first glance, the low alpha-value, .63 (Table 2), was considered to depend on the fact that all these statements were presented in a negative way, which might have been harder to interpret. However, this was not the case. There were big differences between boys and girls in category 6 (boys $\alpha .748$ girls $\alpha$.494). The Cronbach's $\alpha$-level was very sensitive when using few items (10 or less), therefore the inter-item correlation and the individual answers were analyzed. The inter-item correlations should range between .2 and .4 (Briggs and Cheek 1986). The inter-item correlation mean in this case was acceptable (.3) and the category is reliable.

\section{Conclusions and implications}

Even though the qualitative sample only included six students, they gave us much information on how to use and possibly interpret the PATT survey. To conclude, the interviews with students in this study do not point to any validity problems with the questionnaire, since the students seemed to understand most of the questions in the intended way and how to position their answers on a Likert scale. The usage of the middle option on the Likert scale (Burns 1992; de Klerk Wolters 1989; Rennie 1988) with big differences between boys and girls was not observed in the data for this study, even though there were some 
differences. One of the interviewed students lacked the ability to distinguish between technology and skills (see Mitcham and Schatzberg 2009) when he discussed football skills and the technique an electrician uses when connecting wires (same respondent in the quotations under both the headlines Career and Interest). This could be problematic since it is difficult to interpret which of these meanings is referred to when completing the survey. This is a problem that several other countries could also encounter and that the researcher needs to be aware of when using the survey (cf. van Rensburg et al. 1999). In these cases, it might be necessary to add some exclusions that explain the distinction between technology and skills/technique in the survey introduction. It is important though that technology is not explained, since you lose the power of letting the students describe technology themselves in open-ended questions as done by for instance Boser et al. (1998) and Raat and de Vries (1986).

Among the interviewed students there seemed to be connections between their expressed lack of knowledge about technology/technological careers and their mean scores. This might have been because these students had a very limited number of technology classes. Most of the answers were reflections considering either their spare time interest or family members' jobs. This out of school experience points to the importance of technology education for offering a more equitable chance of a technological career for all.

The students' descriptions of interest were similar to what would be considered a welldeveloped individual interest in the four-phase model of interest development by Hidi and Renninger (2006) which is characterized by positive feelings about the subject and a deeper engagement. How they placed themselves on the Likert scale (1-5) indicates how deeply the students' well-developed individual interest in technology is perceived. It is clear that all six statements in the interest category had a high $\alpha$-value (.76, 6 items). If only including the items concerning interest in technology education, though, results in a higher $\alpha$-value $(.79,4$ items). To be able to compare the results regarding interest in technology in general with other PATT studies our recommendation, though, is to continue to survey all six statements. But in order to maintain the existing strong connections between the results in the interest category (PATT-SQ) and the well-developed individual interest as described by Hidi and Renninger (2006), a recommendation is to use the four statements regarding school technology when analyzing the results.

As mentioned, gender is one of the most studied variables when researching attitudes (Potvin and Hasni 2014). This is of course since you often find distinct differences when comparing sexes. This category has to do with how the respondents perceive differences rather than how researchers compare the sexes. The gender category in the PATT-SQ has some obvious problems when it comes to exploring gender differences. The statements in this category seem to trigger gendered reactions to the stated gender differences, and from the interviews, it seems as the students perceive the gender items as invalid statements and therefore do not answer this in a consistent way as a group (individually they do). As a category it is therefore,unreliable, despite an $\alpha$-value of .90 and .87, and cannot be used only by calculating means as it is intended to do. There are basically two problems with the survey that cause these unreliable means. Firstly, the original statements had a larger difference between the sexes than the opposite statements did. This assumption is enhanced by the $t$ tests (see Table 2). Secondly, many of the students disagreed ( 1 on the Likert scale) or used the middle option ( 3 on the Likert scale) for all six statements. Hence an indication of direction is noticeable when comparing the individuals' answers using the opposite stated items as done in this study (Gender $\mathrm{M}$ and Gender F). The interviewees also let us know that they tended to agree that boys might be more capable in technologyrelated tasks, meaning that there are more boys than girls that are capable. 
From the interviews made in this study, it seems that the PATT-SQ survey does detect the high-interest students and students pursuing a technological career. The low-interest students' responses mainly seem to depend on a lack of knowledge about what a technological career might mean. This can be explained by the review by Rohaan et al. (2010); a clearer concept of technology (or in this case, a technological career) can lead to a more positive attitude. This should be taken into account when using and analyzing results from the survey. Of course, a high interest and a will to pursue a technological career are desirable, but since the low mean scores seem to be dependent on the student understanding and knowledge it might be difficult to use the low mean scores in these categories to draw conclusions. The students' knowledge and out of school experience regarding technology seem to be key factors that affect their attitude score, at least for the students that were interviewed in this study. Therefore knowledge given by school about what a technological career might be could improve students' attitudes toward that career so that students' career choices do not depend on out of school experience.

Finally, the results from this study imply that the PATT-SQ survey can be used mostly as it is, but this study also shows that there are some categories that require some caution when being analyzed and discussed. The interest construct advantageously can be reduced to the four items to focus on school technology, this to use the four-phase model of interest by Hidi and Renninger (2006). A recommendation for future users of the PATT-SQ is to use both Gender M and Gender F (the third survey version), as done in this study and calculate the respondent's difference in scores. To avoid the problems with interpretations of technology as skills/technique, an explanation of what is not meant as technology, for example, "technology is not good soccer technology [skills]" should be presented in the survey introduction.

Open Access This article is distributed under the terms of the Creative Commons Attribution 4.0 International License (http://creativecommons.org/licenses/by/4.0/), which permits unrestricted use, distribution, and reproduction in any medium, provided you give appropriate credit to the original author(s) and the source, provide a link to the Creative Commons license, and indicate if changes were made.

\section{References}

Ankiewicz, P., Van Rensburg, S., \& Myrburgh, C. (2001). Assessing the attitudinal technology profile of South African learners: A pilot study. International Journal of Technology and Design Education, 11(2), 93-109.

Ardies, J. (2015). Students' attitudes towards technology: A cross-sectional and longitudinal study in secondary education. Antwerpen: University of Antwerpen.

Ardies, J., De Maeyer, S., \& Gijbels, D. (2013). Reconstructing the pupils attitude towards technologysurvey. Design and Technology Education: An International Journal, 18(1), 8-19.

Ardies, J., De Maeyer, S., Gijbels, D., \& van Keulen, H. (2014). Students attitudes towards technology. International Journal of Technology and Design Education, 25(1), 43-65.

Bain, C. D., \& Rice, M. L. (2006). The influence of gender on attitudes, perceptions, and uses of technology. Journal of Research on Technology in Education, 39(2), 119-132.

Bame, E., \& Dugger, W. (1989). Pupils' attitudes toward technology, PATT-USA, a first report of findings. Retrieved January 09, 2014, from http://www.iteaconnect.org/: http://www.iteaconnect.org/ Conference/PATT/PATTSI/PATT\%20USA.pdf.

Boser, R. A., Palmer, J. D., \& Daugherty, M. K. (1998). Students attitudes toward technology in selected technology education programs. Journal of Technology Education, 10(1), 4-19.

Breckler, S. J. (1984). Empirical validation of affect, behavior, and cognition as distinct components of attitude. Journal of Personality and Social Psychology, 47(6), 1191-1205.

Briggs, S., \& Cheek, J. (1986). The role of factor analysis in the development and evaluation of personality scales. Journal of Personality, 54(1), 106-148. 
Burns, J. (1992). Student perceptions of technology and implications for an empowering curriculum. Research in Science Education, 22(1), 72-80.

Cohen, J. (1988). Statistical power analysis for the behavioral sciences (2nd ed.). Hillsdale, NJ: L. Erlbaum Associates.

Davies, J., \& Brember, I. (2001). The closing gap in attitudes between boys and girls: A 5-year longitudinal study. Educational Psychology: An International Journal Of Experimental Educational Psychology, 21(1), 103-114.

de Klerk Wolters, F. (1989). The attitude of pupils towards technology. Eindhoven: Technische Universiteit Eindhoven.

Fishbein, M., \& Ajzen, I. (1975). Belief, attitude, intention, and behavior: An introduction to theory and research. Reading, MA: Addison-Wesley, cop.

Garmire, E., \& Pearson, G. (2006). Tech tally: Approaches to assessing technological literacy. Washington, DC: National Academies Press.

Hallström, J., Hultén, M., \& Lövheim, D. (2014). The study of technology as a field of knowledge in general education: Historical insights and methodological considerations from a Swedish case study, 1842-2010. International Journal of Technology and Design Education, 24(2), 121-139.

Hendley, D., Parkinson, J., Tanner, H., \& Stables, A. (1996). Pupils' attitudes to technology in key stage 3 of the national curriculum: A study of pupils in South Wales. International Journal of Technology and Design Education, 6(1), 15-29.

Hidi, S., \& Renninger, K. A. (2006). The four-phase model of interest development. Educational Psychologist, 41(2), 111-127.

Krapp, A. (1999). Motivation and learning: An educational-psychological perspective. European Journal of Psychology of Education, 14(1), 23-40.

Krapp, A. (2002). Structural and dynamic aspects of interest development: Theoretical considerations from an ontogenetic perspective. Learning and Instruction, 12(4), 383-409.

Krapp, A., \& Prenzel, M. (2011). Research on interest in science: Theories, methods, and findings. International Journal of Science Education, 33(1), 27-50.

Lindahl, B. (2003). Lust att lära naturvetenskap och teknik? En longitudinell studie om vägen till gymnasiet. Göteborg: Acta Universitatis Gothoburgensis.

Lovelace, M., \& Brickman, P. (2013). Best practices for measuring students' attitudes toward learning science. CBE Life Sciences Education, 12(4), 606-617.

Mitcham, C., \& Schatzberg, E. (2009). Defining technology and the engineering sciences. In A. Meijers (Ed.), Philosophy of technology and engineering sciences (pp. 27-63). Ipswich, MA: Elsevier.

Petersson, B., Hermerén, G., Gustafsson, B., Linklöpings universitet, F. O., \& Linköpings universitet, I. O. (2006). Good research practice-What is it?. Stockholm: Vetenskapsrådet.

Potvin, P., \& Hasni, A. (2014). Interest, motivation and attitude towards science and technology at k-12 levels: A systematic review of 12 years of educational research. Studies in Science Education, 50(1), $85-129$.

Raat, J. H., \& de Vries, M. (1986). What do girls and boys think of technology? Pupils' attitude towards technology: Report [of The] PATT-workshop, March 6-11, 1986, Eindhoven University of Technology. Eindhoven: University of Technology.

Rennie, L. J. (1988). How can we make technology interesting for girls? In J. Raat, R. Coenen-van de Bergh, F. de Klerk Wolters, \& M. de Vries (Eds.), Basic principles of school technology (pp. 397-415). Eindhoven: University of Technology.

Riis, U., \& Augustsson, G. (1991). Att uppfatta teknik—Elva, tolv-och trettonåringars teknikbegrepp och dess beroende av ett antal sociala bakgrundsfaktorer. Linköping: TEMA Teknik och social förändring.

Robson, C. (2011). Real world research: A resource for users of social research methods in applied settings (3rd ed.). Chichester: Wiley.

Rohaan, E. J., Taconis, R., \& Jochems, W. (2010). Reviewing the relations between teachers' knowledge and pupils' attitude in the field of primary technology education. International Journal of Technology and Design Education, 20(1), 15-26.

Skolinspektionen. (2014). Teknik-gör det osynliga synligt. Om kvaliteten i grundskolans teknikundervisning. Stockholm: Skolinspektionen.

The Swedish National Agency for Education. (2011). Curriculum for the compulsory school, preschool class and the recreation centre 2011. Retrieved from http://www.skolverket.se/publikationer?id=2687.

Van Rensburg, S., Ankiewicz, P., \& Myburgh, C. (1999). Assessing South Africa learners' attitudes towards technology by using the PATT (pupils' attitudes towards technology) questionnaire. International Journal of Technology and Design Education, 9(2), 137-151.

Volk, K., \& Ming, Y. (1999). Gender and technology in Hong Kong: A study of pupils' attitudes toward technology. International Journal of Technology and Design Education, 9(1), 57-71. 